\title{
Turizm ve Şehir Vergisi: Kuramsal Bir Analiz ve Türkiye Üzerine Öneriler
}

Tourism and City Tax: A Conceptual Analysis and Proposals on Turkey

\author{
Mustafa DOĞAN* \\ *Yrd. Doç. Dr., Batman Üniversitesi Turizm Işletmeciliği ve Otelcilik Yüksekokulu Batman Merkez Yerleşkesi, PK 72000, Batman. \\ E-posta: mustafa.dogan@batman.edu.tr \\ ORCID: 0000-0001-7648-8469
}

MAKALE BILGILERI

Makale işlem bilgileri:

Gönderilme tarihi: 19 Nisan 2017

Düzeltme: 27 Mayıs 2017

Kabul: 1 Temmuz 2017

Anahtar sözcükler: Sürdürülebilirlik,

Turizm, Vergi, Şehir vergisi,

Uygulama örnekleri, Türkiye.

ARTICLE INFO

Article history:

Submitted: 19 April 2017

Resubmitted: 27 May 2017

Accepted: 1 July 2017

Key words: Tourism, Tax, City tax,

Implementation examples, Turkey.

\begin{abstract}
ÖZ
Turizmde uygulanan vergiler hem alanyazın hem de sektörde önemli bir tartışma alanıdır. Dünyanın birçok ülkesinde, özel olarak sadece turizm sektöründe uygulanan ve turistten alınan özel vergiler ortaya çıkmıştır. Farklı ülkelerde farklı isimler altında olsa da bu vergilerin en yaygını șehir vergisidir. Çalıșmada, șehir vergisinin kavramsal çerçevesi ve uygulama alternatiflerinin sürdürülebilirlik perspektifiyle incelenmesi amaçlanmıştır. Türkiye'de, daha önce teklif edilmesine rağmen yasalaşmayan ve hali hazırda uygulanmayan bu vergiye ilişkin kuramsal bir analiz yapıımış ve uygulamaya yönelik senaryolar tartışıımıştır. Çalışmada, alanyazın ve diğer ülke uygulamaları dikkate alındığında, Türkiye'de șehir vergisinin yeni bir yasal çerçeveyle birlikte uygulanmasının turizm açısından uygun olacağı düşünülmektedir. Türkiye'de şehir vergisinin hayata geçirilmesinin, yerel yönetimler ve sürdürülebilir destinasyonlar için çok yönlü ve ciddi faydalar sağlayacağı öngörülmektedir. Bu bağlamda araştırma, yasal düzenleme ve uygulamaya yönelik öneriler geliștirmiștir.
\end{abstract}

\section{Giriş}

Turizm her yıl tekrarlanan geçici ve kısa süreli ancak kitlesel bir yer değiştirme hareketi olarak değerlendirilebilir. Türkiye son birkaç yıldır nüfusunun yarısı civarında; Fransa, İspanya gibi ülkeler ise nüfuslarından daha fazla sayıda yabanC1 turist ağırlamaktadır (WTO 2017). Bu sayılar, yerli turist hareketleri de düşünüldügünde daha da artmaktadır. Turizm temelli bu hareketlik, her yıl milyonlarca turist ağırlayan ülkeler için önemli bir gelir kaynağı olmasının yanında bazı sorunlara da neden olmaktadır. Turizm sezonu genişledikçe, bu kitlesel yer değiştirme hareketinin yöneldiği ülke, bölge ve yerelliklerde ortaya çıkan ihtiyaç ve buna bağlı sorunlar da artmaktadır. Turizmin maliyeti olarak da değerlendirilebilecek bu sorunlar, destinasyonların çevresel, sosyo-kültürel ve ekonomik ortamlarında gözlemlenmekte ve etkileri değişmektedir.

Turizmin öncelikle doğal ve sosyo-kültürel çevre üzerindeki olumsuz etkilerini azaltmaya yönelik hassasiyet ve çabalar, sürdürülebilirlik yaklaşımının etkisiyle günden güne gelişmektedir. Birleşmiş Milletler Kalkınma Komisyonu (1987) sürdürülebilir gelişmeyi, insanlığın gelecek nesillerin ihtiyaçlarını karşılamayı tehlikeye atmadan bugünün ihtiyaçlarını karşılama yeteneği olarak tanımlamıştır. Sürdürülebilirlik, tüm 
dünyada çevresel sorunlara karşı farkındalık artışı ve devamında ekonomik, sosyal ve kültürel boyutta yaşanan kabul edilemez sorunların çözümünde temel referans haline gelen yaklaşımlardan biridir. Çevresel, ekonomik ve sosyal sürdürülebilirlik sağlandığı takdirde sürdürülebilir gelişme gerçekleşebilmektedir. Küresel turizm sisteminde, turizm sektöründe, ulusal turizm örgütleri ya da turizm ekonomisine bağımlı ülkelerin bazı itirazlarına rağmen, köklü değişimler yaşanmaktadır (Scott vd. 2010). Sürdürülebilirlik yaklaşımının turizm endüstrisine daha yoğun biçimde adapte edilmesi kaçınılmaz görünmektedir.

Turizmde sürdürülebilirlik ilkelerinin uygulanması, destinasyonların çekicilikleri olan doğal, kültürel vb. tüm varlık ve değerlerinin korunması; koruma-kullanma dengesinin sağlanması ve bu değerlerin gelecek kuşaklara da taşınabilmesini amaçlamaktadır. Bu denge, ancak turizmdeki tüm paydaşlar temelinde yapılacak planlamalar ve uygulamalarla mümkündür. Turizmin destinasyonlar üzerindeki olumsuz etkilerini azaltmak; destinasyonların kimliğini, doğasını ve sahip olduğu tüm çekicilikleri korumak ve yaşam kalitesini hem turist hem de yerel halk için geliştirmek amacıyla çeşitli faaliyetlerin yürütülmesine; çalışmaların yapılmasına ihtiyaç duyulmaktadır. Bu faaliyet ve çalışmaları finanse etmek için de ilave ya da yeni ekonomik kaynaklara ihtiyaç duyulmuş ve bunun bir sonucu olarak dünyanın birçok ülkesinde ve şehrinde, konaklama, şehir, koruma vb. isimlerle yeni vergiler hayata geçirilmiştir.

Çalışma, şehir vergisini sürdürülebilirlik perspektifiyle teorik ve uygulamalar çerçevesinde incelenmeyi amaçlamıştır. Mevcut alanyazın ve dünyadaki uygulamaları değerlendirerek, gelecek çalışmalara ve Türkiye için somut uygulamalara alan açabilmek önemsenmektedir. Araştırmanın temel motivasyonu, Türkiye'de halihazırda uygulanmayan bu tür bir vergiye ilişkin tartışmaları biraz daha olgunlaştırabilmek; teoriye ve uygulamaya katkı sağlayabilmektir. Türkiye'de şehir vergisinin yeni bir yasal çerçeveyle birlikte uygulanmasının turizm endüstrisi, yerel yönetimler ve destinasyonlara olası etkilerini tartış- manın ve somut öneriler geliştirmenin önemli olduğu düşünülmektedir.

\section{INCELEME YAKLAŞIMI}

Bu çalışmada öncelikle turizme özgü vergilerin ortaya çıkışı süreci, nedenleri, gelişimi ve bunun turizm endüstrisi içinde arz ve talep yönlü etkilerinin kapsamlı bir şekilde sunulması amaçlanmıştır. Bu bağlamda, turizme özgü ve turistten alınan özel vergiler taranmış; dünyadaki uygulamalarda en yaygın, sektörün paydaşları ve alanyazını açısından da en bilinen tür olan, "şehir vergisi” olgusu ele alınmıştır. Kavramın daha iyi anlaşılması amacıyla, dünyadaki uygulama örnekleri, bilimsel alandaki kuramsal çalışmalar ve alan araştırmaları analitik bir yöntemle incelenmiş ve tartışmalar da dikkate alınarak değerlendirmeler yapılmıştır. Çalışma, şehir vergisini daha çok sürdürülebilirlik yaklaşımı ekseninde ve vergilendirmenin amacı, etkinliği, işlevi ile vergilendirilen açısından gereklilik, meşruiyet, adillik gibi kavramlarla ilişki kurarak tartı̧̧maya odaklanmıştır.

Ziyaretçi için bir destinasyon, sürekli yaşayan sakinleri için bir il, ilçe, belde vb. olarak anılan coğrafi yaşam alanlarında, farklı grupların çeşitli ihtiyaçlarını karşılayacak hizmetleri üreten ve özellikle turizme ilişkin sorunları azaltacak bir paydaş olarak da ortaya çıkan yerel yönetimlerin önemi, gitgide artmaktadır. Türkiye'de henüz uygulanmayan bu vergiye ilişkin, alanyazın incelemesi ile ikincil kaynaklar üzerinden bir kuramsal bir analiz yapılmış ve uygulamaya yönelik olası senaryolar ve etkileri tartışılarak, bu çerçevede Türkiye için somut öneriler geliştirilmiştir.

\section{KAVRAMSAL ÇERÇEVE}

\section{Vergi}

Vergiler güvenlik, altyapı, eğitim, sağlık ve bunun gibi kamu hizmetlerinin gerçekleştirilmesi için ihtiyaç duyulan finansmanı sağlayan önemli bir araçtır (Cural ve Çevik 2015). Vergilendirme, kamu giderlerini karşılamak üzere, gerçek ve tüzel kişiler üzerine konulan her türlü mali yükümlülüğe ilişkin yetkiyi kapsamaktadır. Vergilendirmede temel amaç, devletin kamusal hiz- 
metlere ilişkin finansmanının sağlanmasıdır. Yerel ya da merkezi düzeyde ilgili kurumların bütçelerine aktarılan vergi gelirleri, ihtiyaç duyulan kamusal hizmetler için harcanmaktadır. Vergi ile ilgili önemli konulardan biri, vergi ödeyenlerin, toplanan vergilerin gerekçesi, amacına uygun harcanması ve adilliği konularındaki hassasiyetidir. Bu tür hassasiyetler, farklı toplum ve ülkelerde şiddeti farklı olsa da genellikle tüm vergilere ilişkin görülebilmektedir. Vergilerin toplanması ve harcanmasındaki şeffaflık, mükellefler için vergiye katılımı da etkileyen, dolayısıyla mükellefin kendi vergi yükünün adil olmadığını alg1laması, vergi uyumsuzluğunu yaratan önemli bir faktördür (Serim 2014: 144). Bu nedenle vergide adalet ve etkinlik, iki önemli ilke olarak ortaya çıkmaktadır (Gooroochurn ve Sinclair 2003).

Feld ve Tyran (2002), ampirik çalışmalarında, kanunların adil olduğunu algılayan vatandaşların, vergi kanunlarına uyumunun da yüksek olduğu ortaya çıkmıştır. Vergi mükelleflerine saygilı bir yaklaşım ve şeffaf prosedürler uyguland1ğında; mükellefin gönüllü uyumu ve yükümlülük duygusuyla üzerlerine düşen vergiyi ödeme olasılığı daha yüksek; vergi kaçırma ihtimaliyse daha düşüktür (Kircheler vd. 2008: 211). Vergilerin gerekçesi, hangi amaçla toplandığ1 ve nerelere harcanacağı konusundaki genel çerçeve, yerel, bölgesel ya da ulusal düzeydeki yasal düzenlemeler, ilgili yönetimlerin yasal organları tarafından belirlenebilmektedir. Avrupa'da İtalya, Hirvatistan, Almanya gibi çoğu ülkede, bu tür vergileri koyma yetkisi ve ilgili yasal düzenlemeler, şehir yönetimleri, yerel meclisler, belediyeler gibi yerel yönetim organları tarafından yapılırken baz1 ülkelerde (ABD, İspanya) eyalet yönetimi ya da bölge valiliği gibi merkezi yönetim kuruluşları tarafından yapılmaktadır. Bu durum ülkelerin yönetim biçimleri, idari yapısı, merkezi-yerel yönetim ilişkisi, Anayasa ve yasalarına bağlı olarak değişmektedir. Türkiye'de, vergi koyma, kaldırma ve değiştirme yetkisi, sadece yasama organı tarafından yerine getirilmektedir. Ancak anayasal düzenlemeye göre verginin oranları, indirimler, muaflık ve istisnalara yönelik, yasada belirlenen alt ve üst sınırlar içinde değişiklik yapma yetkisi, Bakanlar Kuruluna da verilebilmektedir (Yakar ve Budak 2013).
Toplumun hangi kesimlerinin vergilerin mükellefi olması gerektiği konusunda, daha yüksek gelire sahip olanların öncelikle vergilendirilmesinin daha adil olduğuna yönelik bir eğilim bulunmaktadır. Gelirdeki artışa paralel olarak artan bu vergilendirme yaklaşımından hareketle, turizm talebinde bulunanların vergilendirilmesinin adalet ilkesine uygun olduğu ifade edilmektedir (Hughes 1981; Weston 1983). Turizm talebi için diğer faktörler sabit kalmak kaydı ile harcanabilecek gelirdeki artış ile talep arasında doğrusal bir ilişki olduğu bilinmektedir. Ancak yine de verginin gerekçesi, niçin ve hangi hizmetler için harcandığı bilgisi, talebin sahibi olan turistin r1zası için de önemli bir etkendir.

\section{Şehir Vergisi}

Turizm, gelir yaratıcı önemli bir sektör olarak görülmektedir ancak turist için çekici olan çoğu destinasyon, aynı zamanda yerleşik nüfusu ve gündelik hayatı olan bir alanıdır ve bu alanların yaşam kalitesi hem sakinleri hem de ziyaretçileri için önemlidir. Altyapı, yol, enerji, su, temizlik, atık, peyzaj, ulaşım, denetleme vb. gibi hizmetler genellikle o destinasyonun idari sorumlusu olan yerel yönetim birimleri tarafından üretilmekte ve karşılanmaktadır. Yoğun turizm dönemlerinde, ziyaretçi sayısı yerleşik nüfusa yakın olan ya da onu aşan destinasyonlarda, bu hizmetlerin karşılanması yerel yönetimler için önemli bir sorun haline gelmektedir. Bu verili durum, destinasyonların ortalama bir yaşam kalitesinin sakinleri ve ziyaretçileri için tesis edilmesi ve bunun sürdürülebilir olmasının zorluğunu göstermektedir. Bir bölgede resmi ikamet eden nüfusa göre planlanan tesis, altyapı vb. gibi olanaklar ve hizmetler turizm destinasyonları için özellikle yüksek sezonlarda yetersiz kalmakta, gerek turistin gerekse yerel halkın ihtiyaç duyduğu birçok hizmetin verilmesinde sorunlar yaşanmaktadır. Bu nedenle turisti kabul eden, ağırlayan ülkeler ya da destinasyonların doğrudan; o bölgelerde yaşayan yerel halkın ise dolaylı olarak yararlandığ 1 bazı özel vergiler, aynı zamanda bölgede turistin neden olduğu maliyetin bir karşılığı olarak görülmektedir (Gooroochurn ve Sinclair 2005; Brida ve Pereyra 2007). 
İlk kez New-York'ta Otelciler Birliği'nin sert biçimde karşı çıkmasına rağmen 1946 yılında sadece yabancı turistlere yönelik uygulamaya konulan bu tür özel vergiler, özellikle 1980'li yıllardan sonra yaygınlaşmış (Ford ve Peeper 2007) ve $A B D$ 'nin 50 eyaletinin tamaminda ve 150 şehirde uygulanır hale gelmiştir (Bender 2007; USA Tax Report 2014). Şehir, konaklama, oda, yatak vb. gibi farklı isimlerle anılan ancak özünde benzer olan vergiler; bir coğrafi yönetim alanında yaşayan-ikamet edenlerin dişında, o bölgeyi d1şardan ziyaret eden yerli ya da yabancı uyruklu turistlerin sunulan hizmetlere maddi katılımını düzenleyen, turizm kaynaklı bir vergi olarak ortaya çıkmaktadır. Katma Değer Vergisi (KDV) ve tüketim vergisi gibi genel vergilerin dışında, bunlara ilaveten uygulanan bu vergilerin mükellefi sadece turistlerdir. Ad Valorem bir vergi türü olarak, konaklama işletmelerinin gecelik konaklama ücretlerine, belirli oranın ya da tutarın ilave edilmesi suretiyle uygulanmaktadır.

Bu vergi gelirleri, devletin ulusal-merkezi bütçesinden çok, yerel yönetimlerin bütçelerine aktarılmakta ve turistin ziyaret ettiği yerellikteki harcamaları finanse etmek için kullanılmaktadır. Turist açısından toplanan vergilerin, kalınan şehir ya da coğrafi bölgedeki kamusal düzen ve onun ihtiyaçları için harcanacak olması ve bunun ölçek itibarıyla gözlemlenebilir olması önemlidir. Özellikle vergide şeffaflık ilkesi gereği, yapılan hizmet ve harcamaların bilinebilir olmasi; turistin ve yaşayan halkın ihtiyaçları da dahil olmak üzere, yereldeki ortak ihtiyaçlar için kullanılması, bu tür vergilendirmelerde kolaylaştırıcı bir unsur olarak görülebilir.

$B u$ vergilerin yerel düzeyde planlanması ve toplanmasi; elde edilen kaynağın doğrudan turizmin geliştirilmesi, turizm endüstrisinden kaynaklı olumsuz etkilerin durdurulması amaciyla kullanılması konusunda genel bir eğilim bulunsa da yerel düzeyde ulaşım, taşımacılık, altyapı, kültür, sanat vb. gibi turizmi dolaylı olarak destekleyen alanlar için harcandığ 1 da belirtilmektedir (Hiemstra ve İsmail 1992). ABD'de yapilan araştırmalarda toplanan vergilerle oluşturulan fonun hem turizm için harcanmasına (Weston 1983; Hiemstra ve İsmail 1992a; Hiemstra ve İs- mail 1993; Bender 2007) hem de yerel yönetimin genel harcama bütçesine aktarılmasına izin veren yasal düzenlemeler olduğu (Spengler ve Uysal 1989) görülmektedir. Almanya Hamburg'da ise kültür ve turizm vergilerinin \%100 turizme yatırılacağı; Hamburg'un imajı, kültürel ve sportif projeler için kullanılacağına dair politik söz verilmiştir (Hamburg Tourismus 2016).

Turizmde doğal ve sosyo-kültürel çevrenin kalitesi, altyapı olanakları ve üstyapı tesislerinin çekicilikleri, destinasyonun turizm talebini etkileyen önemli faktörlerdir. Turizm destinasyonlarının başarısı, bu çekiciliklerin kalitesinin korunması ve sürekliliğinin sağlanmasıyla mümkündür (Fick ve Ritchie 1991; González ve León 2001; Pintassilgo ve Silva 2007). Turizmin ve turistin destinasyonla ilişkisi günümüzde, belediyecilik hizmetlerinin kapsamını da aşan daha geniş bir boyuta taşınmıştır. Geçmişte yerel yönetim birimlerinin, turistik yoğunluğa bağl olarak ortaya çıkan ihtiyaçlarının finansmanı olarak düşünülen özel vergilerin kapsamı, bugün daha da genişlemiştir. Fiziksel ve doğal çevrenin korunması, biyo-çeşitliliğin sağlanması, endemik türlerin koruma altına alınması, somut ya da soyut kültürel miras değerlerinin korunması ve geleceğe taşınması gibi destinasyonların turistik çekiciliğini doğrudan ya da dolaylı olarak etkileyen birçok alanda ihtiyaçlar ortaya çıkmıştır. Bir destinasyonun gerek turizm gerekse gündelik yaşam açısından sürdürülebilirliğini sağlamaya yönelik ihtiyaç ve beklentiler artmaktadır. Bu nedenle turiste özel vergilerin sürdürülebilirlik eksenli kurgulanması ve gerekçelendirmesi; şehir ile sürdürülebilirlik amaçlı vergiler arasında rasyonel bir ilişkinin kurulması önemli hale gelmektedir.

\section{ALANYAZIN}

Turizm sektörüne özgü vergiler konusundaki çalışmalar daha çok bu vergilerin arz ve talep üzerindeki ekonomik etkilerine odaklanmıştır. Turizm talebinin bu tür vergilere karşı esnek olup olmadığ (elastik-inelastik) hep önemli bir araştırma ve tartışma alanı olmuştur. Mak (1988), bu tür özel vergilerin oda fiyatlarına geçmesini ve konaklama fiyatlarını yükseltmesinin etkilerini incelemiş; vergiden elde edilen fonların turizmin 
gelişmesi için kullanılması durumunda, verginin olumsuz etkilerini azaltacağını tespit etmiştir. Pindyck ve Rubinfeld (1992: 315) talebin esnek olduğu durumda üreticilerin yani konaklama işletmelerinin bu yükü üstleneceğini; esnek olmadığ 1 durumda ise tüketicilerin ilave vergiyi ve vergiye bağlı daha yüksek fiyatı ödeme eğiliminde olduklarını varsaymaktadır.

Turizmdeki diğer vergilere göre şehir ya da konaklama vergisinin potansiyel olarak daha etkili olduğu (Weston 1983); seçmenden değil turistten alındığ 1 için politik olarak da sorunsuz ve kolay tahsil edilebildiği (Hughes 1984: 75) değerlendirilmiştir. Bu vergi, kalıcı ikametinden geçici süreyle ayrılan turistin, gittiği yerlerde geçici süreyle aldı ̆̆ 1 yerel hizmetler, yararlandığı olanaklar ya da çevreye verdiği zararın bir karşıllı̆̆ı olduğu düşünüldüğünde, adil kabul edilmektedir (Bender 2007).

Şehir vergisi ve benzeri uygulamalar geçmişte ekonomik temelli ve daha çok yerel yönetimlerin finansman ihtiyacı için ortaya çıssa da günümüzde sürdürülebilirlik eksenli gerekçeler de belirleyici olmakta ya da etkili hale gelmektedir. Alan araştırmasına dayalı çalışmalar, daha çok Amerika ve sinırlı olarak Avrupa ülkelerindeki uygulamalar üzerine yapılan ve ekonomik etkiye yönelik araştırmalardır. Sürdürülebilirlik, çevre ve turizm ilişkisi üzerinden turist ya da diğer paydaşların algı ve tutumları üzerine yapılan çalışmalar ise sinırlıdır. Onlardan biri olan Twining ve Butler (2002) ise yaptıkları araştırmada, turistlerin sürdürülebilir turizm ve destinasyon yönetimi amaçlı olan bu tür özel vergilere katılımının yüksek ve bakışının olumlu olduğu sonucuna ulaşmışlardır. Farklı bir araştırmada ise daha spesifik olarak deniz-kum-güneş odaklı turistlerinin şehir vergisini ödemede düşük; buna karşın doğa odaklı, çevreci ve mütevazi turistlerin ise daha yüksek eğilimde oldukları tespit edilmiştir (Valle vd. 2012). Bu durum farklı turizm türleri ve farklı turist tiplerine hassasiyet, göre alg1 ve tutumların farklılaşabildiğini göstermektedir.

Türkiye'de yapılan çalışmalar ise oldukça azdır ve alanyazının bu alanda daha fazla kuramsal ve ampirik çalışma ile geliştirilmeye ihtiyacı bulunmaktadır. Bu alandaki ilk çalışmada Bozdanoğ- lu (2013) eski yasa tasarısı üzerinden konaklama vergisinin uygulanabilirliğini tartışmış ve uygulamaya yönelik öneriler sunmuştur. Gürel (2014) ise şehir vergisinin uygulanabilirliğini İstanbul örneği üzerinden ve turizm endüstrisinin konaklama işletmeleri temsilcileri ile değerlendirmiş ve sektörün, bu uygulamaya mesafeli yaklaştığını hatta karşı olduğunu tespit etmiştir. Buna rağmen her iki çalışma, bu uygulamanın Türkiye turizmi için olumlu etkileri olacağını değerlendirmektedir.

\section{ŞEHIR VERGISI UYGULAMALARI VE DÜNYADAN ÖRNEKLER}

Şehir vergisi bugün, Avrupa, Amerika, Uzak Asya ülkelerinin çoğunda, hatta Birleşik Arap Emirlikleri gibi Arap ülkelerinde de uygulanır hale gelmiştir. AB üyesi ülkelerde konaklama vergisi uygulamasının yasal dayanağ $\mathrm{KDV}$ uygulamasında da değişikliklerin (282/2011) yer aldığ 1 2006/112/EC sayıl1 Konsey (Official Journal of European Union, 2011) kararıdır. Verginin mükellefi; kısa süreli ve geçici konaklamalar için konaklama tesislerini kullananlar olarak tanımlanmıştır. Almanya'da konaklama vergileri "Kültür Vergisi" ve "Yatak Vergisi" olarak uygulanmakta olup konaklama zamanına, kalınan otelin oda sayısına, konaklama tipine, konaklanan odanın gecelik ücretine göre farklılık gösteren oranlarda uygulanmaktadır (Bozdoğanoğlu 2013:135). Belçika'da Şehir Vergisi adıyla yerel yönetimler tarafından toplanan vergi; Antwerp, Bruges, Brüksel ve Ghent şehirleri için oteldeki oda sayısı ve gecelik konaklama fiyatı temel alınarak $\% 1,8$ oranında uygulanmaktadır. Hollanda'da "Turist Konaklama Vergisi” ülkenin 421 belediyesinin neredeyse tamaminda oran (\%4,5 ile $\% 5$ arasında) ya da miktar (ve 0,30 ile 3,90 Avro arasinda) usulü ile uygulanmaktadır (Bozdoğanoğlu 2013). İspanya'da 2011'de yasalaşmış olan "Turizm Vergisi", 2012'den beri Katalan bölgesindeki tüm otellerde uygulanmaya başlamıştır. Verginin tutarı bölgelere ve otel kategorilerine göre 0,75 Avro ile 2,5 Avro arasında değişmektedir. Avusturya'da konaklama üzerinden alınan vergi; karavan ve kamp alanlarını da kapsamakta olup kişi başı gecelik 0,15 Avro ile 2,18 Avro arasında 
değişmektedir. Portekiz'de 1 Ocak 2016'dan itibaren başkent Lizbon'a havayolu ve denizyolu ile gelen tüm turistlerden şehir vergisi adı altında alınan kişi başı 1 Avro ve otellerde konaklayan tüm turistlerden de gecelik 1 Avro konaklama vergisi uygulamasına başlanmıştır (Tourism Review 2016).

İtalya'nın birçok şehrinde 2011 yılından itibaren uygulanan şehir vergisi, tesisin niteliğine ve konaklanan gece sayısına göre farklılık göstermektedir. En yüksek vergiler Roma'da olup gecelik en düşük 1, en çok 3 Avro olarak tahsil edilmektedir. Rusya'nın turistik açıdan iki önemli şehri Moskova ve St. Petersburg'da 2011'den itibaren değişen tutarlarda şehir vergisi alınmaya başlanmıştır. Hırvatistan'da günlük kişi başı 0,25 Avro ile 1 Avro arasında değişen tutarlarda şehir vergisi alınmakta ve şehirler turist çekme kapasitesine göre kategorilere ayrılmakta, örneğin Dubrovnik A kategorisinde yer almakta olup en yüksek vergi oranda bu şehirde uygulanmaktadır (Bozdanoğlu 2013). Hirvatistan sezon ve bölge temelli uygulamasıla Avrupa'daki diğer ülkelerden farklılaşan bir özelliğe sahiptir.

ABD'de, şehir vergisi (City Tax), otel doluluk vergisi (Hotel Occupancy Tax), konaklama vergisi (Lodging Tax) ya da otel vergisi (Hotel Tax) isimleriyle uygulanmakta olan ve tutarları eyaletlere göre farklılık gösteren verginin, uygulama şekli ise birbirine benzemektedir. 30 güne kadarlık kısa süreli konaklama amacıyla kiraya verilen daireler de dahil olmak üzere otel, motel, kamping, bungalov, oda-kahvaltı hizmeti veren yerler dahil edilmiştir. New York'ta şehir vergisi, oda başına gecelik 3,5 USD olarak tahsil edilmektedir. Washington'da vergi tutarı 0,5 Dolar ile 2 Dolar arası olup otelin oda kapasitesine göre değişiklik göstermektedir. Japonya'nın başkenti Tokyo'da uygulanan şehir vergisi turizmi geliştirmek, turizm sektörüne yapılan harcamaları artırmak ve şehrin turist çeken özelliklerine katkı sağlamak amacıyla 2002'den bu yana başlatılmıştır (Bozdanoğlu 2013). Yunanistan'da KDV'ye ek olarak $\% 0,5$ oranında şehir vergisi uygulanmakta olup (The Town of Greece 2016) bu oran Yunan adalarında da geçerlidir.

\section{TARTIŞMA: ŞEHIR VERGISININ TÜRKIYE'DE UYGULANABILIIRLIĞi}

Turizm endüstrisinin iki önemli ayağ 1 olan konaklama ve seyahat işletmelerinin sektöre özgü vergilere çoğunlukla karşı olduğu, yapılan araştırmalarla (Hughes 1981; Winkelblech vd. 1998; Bender 2007) desteklenmişse de bazı araştırmalarda (Weston 1983) toplanan vergilerin doğrudan turizmi geliştirmek için kullanılması halinde bu kesimlerde de kabul edilebilir karşılandığı görülmüştür. Özellikle konaklama işletmeleri, yerel yönetimlerin görev alanına giren bu hizmetlerin maliyetinin bir kısmının turistlere kaydırılması$\mathrm{n} 1$, rekabet güçlerine zarar veren haksız bir araç ya da uygulama olarak görme eğilimindedir (Aguilo vd. 2005). Yerel yönetimler açısından şehir vergisi hem ekonomik hem de politik olarak rasyonel görülmekle birlikte, elde edilen vergi gelirleriyle turist-dostu bir çevrenin iyileştirilmediği, turizm kaynaklı yerelde artan altyapı ve üstyapı ihtiyaçlarının karşılanmadığı ve bu olanakların geliştirilmediği koşullarda (Knipe 2011) önemli sorunlar yaşanması (Hughes 1981) muhtemeldir. Bu nedenle şehir vergisi ile elde edilen fonların, hangi kurumların bütçelerine aktarılacağı, nasıl harcanacağ $\breve{1}^{2}$ e hangi hizmetler-faaliyetlerin finansmanı olacağı önemlidir.

Bu tür vergilerin turizm talebini ve özelde konaklama işletmeleri talebini olumsuz etkileyip etkilemediğine yönelik yapılan araştırmalarda (Mak ve Nishimura 1979; Combs ve Elledge 1979; Hiemstra ve Ismail 1992; Fujii vd. 1985; Bonham vd. 1992; Bonham ve Gangnes, 1996; Damonte vd. 1998; Canina ve Carvell 2005, Aguiro vd. 2005) talebin, konaklama fiyatındaki vergi kaynaklı artışa genel olarak esnek olmadığı ve vergi kaynaklı fiyat artışlarından etkilenmediği tespit edilmiştir. Turizm endüstrisinin eleştiri ya da şikâyetlerine rağmen bu tür vergilerin, otellerin toplam gelirleri üzerindeki negatif etkisinin olmadığı ya da küçük olduğu görülmektedir (Bonham vd. 1992; Bonham ve Gangnes 1996, Mak 1988, Aguilo 2005). Mak ve Nishimura (1979) Hawaii için yürüttükleri araştırmada, \%1 oranında uygulanan oda vergisi ile 2,7 milyon dolar ek gelir elde edildiği ve bu verginin talebi olumsuz yönde etkileme açısından önemsiz, turist için de 
ihmal edilebilir düzeyde olduğu sonucuna ulaşmışlardır. Hawaii için 1980 ile 1990 yılları arasındaki on ylllık süreci inceleyen Bonham vd. (1992) şehir vergisi uygulanmadan önceki ve sonraki dönemi karşılaştırmışlar ve şehir vergisinin otel satışları ve gelirleri üzerinde negatif bir etkiye neden olmadığını tespit etmişlerdir. Arguea ve Hawkins (2015) Florida'daki 1998 ve 2012 yılları arasında, konaklama vergi oranlarındaki periyodik artışların birkaç önemli ve kısa vadeli düşüşe neden olmasına rağmen uzun vadede önemli etkileri olmadığını hesaplamışlardır. Aguilo vd. (2005) Balear Adalarında konaklayan İngiliz, Hollandalı, Alman ve Fransız turistler üzerinde yaptığ ${ }_{1}$ araştırmada, şehir vergisinin turizm talebini olumsuz etkilemediğini ortaya çıkarmıştır.

Yine de kabul edilebilir seviyelerin üzerinde şehir vergisi oranları, tüketicinin nihai kararı üzerinde olumsuz yönde etkili olabilir. Bu durumun turist üzerinde konaklama süresi, türü, yerini değiştirme ya da eğlence, dış aktiviteler ve yeme-içme masraflarını azaltma gibi etkilere neden olabileceği düşünülmektedir (Mak ve Nishimura 1979; Hiemstra ve Ismail 1992a; 1992b). Örneğin New-York özelinde yapılan bir çalışmada (Bender 2007) 1990'ların başında turizmde çok yüksek orandaki özel vergilerin tahsil edilen toplam yıllık vergi miktarını azalttı̆̆ı; yüksek konaklama vergilerinin fiyata karşı esnek olan tüketiciyi olumsuz etkilediği tespit edilmiştir (Arbel ve Ravid 1983; Fujii vd. 1985; Sakai1985). Ayrıca Canina ve Carvel'in (2005) çalışmasında, küçük otellerde kalan turistlerin bu vergilere karşı daha hassas olduğu; büyük oteller ile özellikle şehir otellerinde kalan turistlerin ise bu vergileri önemsemediği görülmüştür. Demonte vd. (1998) ise vergilere bağlı talebin fiyat esnekliğinin, destinasyona göre farklılaştığını; bir destinasyonda turistlerin bu tür vergileri etkileme düzeyi düşükken başka bir destinasyonda yüksek olabildiğini ortaya çıarmıştır. Lee (2014) ise konaklama-yatak ya da otel doluluk vergisi adı altında ilave vergi uygulamasina sahip olan ve olmayan iki destinasyonu rekabet açısından incelemiş ve bu verginin uygulayamaya sahip destinasyonun rekabet gücünü olumsuz etkilediğini belirtmiştir.

Türkiye'de de turizm endüstrisinin temsilcileri benzer bir hassasiyetle konaklama üzerinden alınacak bir verginin turizm talebini ve uluslararas1 rekabeti olumsuz etkileyeceği gerekçesiyle bu uygulama fikrine genel olarak mesafeli durmaktadır (Gürel 2014). Ancak Akdeniz çanağında bulunan ve Türkiye'nin temelde rekabet ettiği İspanya, İtalya, Fransa, Yunanistan, Portekiz, Hırvatistan gibi ülkelerin tamaminda, bu vergiler uygulanmaktadır. Ayrıca turist profili açısından bakıldığında, Türkiye'yi ziyaret edenlerin yüzde 60'a yakını (Kültür Bakanlığı 2016; TURSAB 2017) Avrupa ülkelerinden gelen ve bu uygulamaya aşina olan turistlerden oluşmaktadır. Vergi uygulamasında rekabet halindeki ülkeler ve uygulanan oran ya da miktarlar dikkate alınarak bir oran belirlenebilir. Örneğin en yakın ve temel rakiplerden biri olan Yunanistan'daki oran temel alınarak rekabetin olumsuz etkilenmemesine yönelik bir strateji geliştirilebilir. Bununla birlikte, yerli turist açısından şehir vergisi yeni bir vergi olarak düşünülebilir ve etkisi yabancı turiste göre daha farklı ve olumsuz düzeyde gerçekleşebilir.

Birleşmiş Milletler Dünya Turizm Örgütü'nün araştırmalarına (UNWTO Report 2009) göre, gelişmiş Avrupa ülkelerinden gelen turistlerin çevresel hassasiyetleri, sürdürülebilirliğe bakış açıları ve sürdürülebilir turizm tercihleri sürekli artmaktadır. Dolayısıyla sürdürülebilir turizm ve uygulama amaçlı vergi-katkı vb. uygulamaların, Türkiye'nin uluslararası rekabetini olumsuz etkileme ihtimali, özellikle kültür turizmi bağlaminda düşük olabilir. Turizm türü ve turist tipleri dikkate alındığında, özellikle deniz kum güneş turizmi açısından bazı destinasyonlarda turistin ve sektörün göstereceği tepkilerin, ilk etapta daha yüksek olması beklenebilir. Özellikle kitle turizminin önemli unsurlarından biri olan fiyat temelli, düşük ve orta gelire sahip yabancı turistler açısından şehir vergisi destinasyondan cayma nedeni potansiyeli taşısa da kültür turistleri için bu ihtimal düşüktür. Bu ihtimali de destinasyona göre farklılaşan vergilendirme yöntemi ile hafifletmek mümkün olabilir. Bununla birlikte dünyadaki uygulamalar ve gelinen süreç, sürdürülebilirlik imajı ve uygulamalarıyla desteklendiğinde bu verginin turizm talebini olumsuz etkileyen bir faktör olma ihtimalinin azalacağını göstermektedir. 
Şehir vergisine esas olan dünyadaki yaygın uygulama, gecelik konaklama bedeli için oda ve kahvaltı dahil fiyattır ve konaklama dişında kalan hizmetlerin bu vergiye dahil edilmemesi şeklindedir. Oda-kahvaltı pansiyon dışında Yarım Pansiyon, Tam Pansiyon, Herşey Dahil gibi daha farklı pansiyon türlerinde hizmet veren ve konaklama bedeli fiyatlandırması buna bağlı olan konaklama işletmeleri açısından bunu ayırmak ya da vergi matrahını belirlemek uygulamada zor olabilir. Bu nedenle dünyadaki yaygın uygulamalar dikkate alındığında, Türkiye için destinasyona ve konaklanan tesisin türüne göre farklılaşan bir vergilendirme uygulamasına gidilebilir. Türkiye için Hollanda ve Hırvatistan'da uygulanan ikili sisteme benzer bir yapı uygun olabilir. Konaklama bedeli üzerinden oransal bir şehir vergisinin tutara eklenmesi ya da konaklama bedeline ek bir sabit verginin ayrıca fatura edilmesi, uygulama için daha işlevsel bir yöntem olarak değerlendirilebilir. Örneğin, kültür turizmi ağırlıklı destinasyonlar olan İstanbul ve Nevşehir için oransal bir şehir vergisi uygulanırken, deniz turizmi ağırlıklı Antalya, Muğla için sabit ve daha düşük bir vergi miktarı uygulanabilir. Oran ve tutarlar destinasyona ve konaklanan tesisin türüne göre farklılaştırılabilir ve destinasyonlar için gelişmiş ve gelişmekte olan ayrımı oran ve miktarlar belirlenirken dikkate alınan bir kriter olabilir. Örneğin Bozdanoğlu (2013) turizm açısından gelişmekte olan ve gelişmiş bölgeler sinıflandırması ve bu bölgelerde farklı miktarlarda vergi önermiştir. İstanbul için \%1'lik bir oranın belirlendiğini düşünülürse, 2016 yılı için İstanbul'da ortalama gecelik oda fiyatının $68 \mathrm{Av}$ ro olduğu (TÜROB 2017) ve geceleme sayısının Kültür Bakanlığı' nın 2016 yılı verilerine göre ortalama 15 milyon olduğu kabul edilirse elde edilecek gelir (0,68 Avro x 15 milyon geceleme) 10 milyon Avro civarında olacaktır.

Uygulamaya ilişkin diğer bir sorun, vergi mükellefinin sadece yabancı turist mi olacağı, yoksa hem yerli hem yabancı turist mi olacağıdır. Dünyadaki uygulamalara bakıldığında, hakim uygulamanın milliyet-ülke ayrımı yapmaksızın verginin, yerli ve yabancı tüm turistlere uygulanması yönündedir. Türkiye'de de uygulamanın yerli-yabancı ayrımı yapmaksızın tüm turistler için uygulanması önemlidir. Burada müze ve ören yerleri giriş ücretlerinde olduğu gibi vatandaş ile yabancı arasında bir farklılaştırmaya gidilmesi tartışılabilir ancak mükellefler açısından vergi adaleti ve tüketicinin bu konudaki hassasiyetlerini dikkate almak gereklidir. Bu açıdan yerli veya yabancı turist için aynı oranlarda geçerli olacak bir vergilendirmenin daha adil olacağ düşünülmektedir.

Türkiye'deki konaklama işletmeleri açısından halihazırdaki ikili yapı (Kültür ve Turizm Bakanlığı Belgeli ve Belediye Belgeli tesisler) büyük oranda kalite, standart ve uygulanan fiyatlar aç1sindan da belirleyicidir. Belediye belgeli pansiyon veya oteller kapasite, hizmet, kalite ve fiyat olarak da Bakanlık belgeli tesislere göre genellikle daha düşüktür. Aynı zamanda Bakanlık veya Belediye belgeli olsun pansiyonlar, apart oteller ve hosteller, diğer konaklama işletmelerine göre daha düşük standartlar ve fiyatlara sahiptir. $\mathrm{Bu}$ tür tesislerde kalan turistler için daha düşük, 3 yıldız ve üzeri oteller, tatil köyleri ve butik otel, özel tesis kategorisindeki konaklama işletmelerinde kalanlar için daha yüksek bir vergi tutarı öngörülebilir. Aynı zamanda Bakanlık belgeli tesislerin de kendi içindeki yapılan sınıflandırmada yine kalite, standart ve fiyatlar 1 yıldızlı otelden 5 yıldızlı otele doğru artmaktadır. Bu nedenle Belediye belgeli konaklama işletmesinde konaklayan düşük bütçeli bir turist daha düşük bir vergi öderken, Bakanlık belgeli 3 yıldızlı bir otelde kalan turist daha çok vergi ödeyecek; aynı zamanda 1 yıldızlı bir otelde konaklayan turistin, 5 yıldızlı otelde kalan turiste göre daha az vergi vermesi sağlanacaktır.

Şehir vergisinden elde edilen fonların nasıl harcanacağı; hangi amaçlar için belediyeler tarafından kullanılabileceği konusunda yasada bir tanımlama ve sinırlama getirilmesi gereklidir. Verginin meşruiyeti, adilliği ve işlevselliği buna bağlıdır. Şehir vergisinin amaçları, onun tüketici açısından gerekçelendirilmesini ve meşruiyetini de belirleyecektir. Şehir vergisinden elde edilecek fonların kullanım amaçlarına ilişkin öneriler şöyledir:

- Belediyelerin faal olduğu turistik bölgede (destinasyon) turizmin geliştirilmesine doğrudan 
katkı sağlayacak (tanıtım, imaj, araştırma-geliştirme, çevresel düzenlemeler, teknolojik hizmetler, altyapı, üstyapı çalışmaları vb.) faaliyetlerini gerçekleştirmek,

- Sürdürülebilir gelişme ve turizm amaçlı faaliyetlerin güçlendirilmesi; buna katkı sağlayacak paydaş eğitimleri vb. farkındalık faaliyetlerini yapmak,

- Turistin destinasyondaki deneyimlerini, hizmet kalitesini ve memnuniyetini artıracak düzenlemeleri hayata geçirmek,

- Taşıma kapasitesinin aşıldığı ya da zorlandığı turizm dönemlerinde, hizmet vermenin yetersiz kaldığ alanlarda ekipman, teçhizat, personel vb. destekleri sağlamak,

- Belediye sınırları içinde ikamet eden yerel toplumun turizmin yoğun olduğu dönemlerde maruz kaldığı sorunları azaltacak ve yaşam kalitesini artıracak uygulamaları yapmak,

- Turizmden kaynaklanan doğal, çevresel tahribatın azaltılmasını; doğal ve kültürel mirasın korunmasını, geliştirilmesini sağlamak,

- Turizmle doğrudan ve dolaylı her türlü politika ve stratejik gelişim planlarını yapmak ve uygulamak,

- Akıllı şehir ve akıllı destinasyon yönetimi gibi elektronik uygulamalar ve ağlar oluşturmak amaciyla kullanılmalıdır.

Şehir vergisine ilişkin önemli konulardan biri de bu vergiden kimlerin ya da hangi toplumsal kesimlerin muaf olacağına ilişkindir. Bu sınırın ve vergi muafiyetlerinin yasada belirlenmesi zorunludur. Dünyadaki örnek uygulamalar dikkate alındığında aşağıdaki kişi ya da grupların şehir vergisinden muaf tutulması önerilebilir;

- Konaklama işletmesinin bulunduğu Büyükşehir, il, ilçe ya da beldede yaşayanlar, yani yasal olarak ikamet eden yerli ve yabancı vatandaşlar,

- 12 yaşına kadar olan çocuklar,

- Hastalık nedeniyle, tedavi, zorunlu bakım vb. amaçlı gelenler,

- Diplomatik, siyasi, güvenlik amaçlı seyahat eden kamu çalışanları,
- Turist rehberleri, acenta sorumluları, pilot, kaptan, hostes vb. gibi turizm çalışanları (İşin bir parçası olarak ziyaret ediyorlarsa)

Şehir vergisinden elde edilen fonların klasik belediyecilik hizmetleri dışında, destinasyonun daha sürdürülebilir hale gelmesini sağlayacak politikaları, planları, uygulamaları fonlaması ve ayrıca elde edilen fonun hangi faaliyetler için harcandığına dair bilgilerin, şeffaf biçimde kamuoyu ile paylaşılması önemlidir. İlk yapılacak faaliyetlerin başında, yerel ve bölgesel düzeyde sürdürülebilir turizm gelişim planlarının yapılması ve bu planlara uygun stratejilerin oluşturulması gelmektedir. Stratejik gelişim planlarında vergilerden elde edilecek gelire bağlı olarak turizmin yerel düzeyde geliştirilmesi ve yerel yönetimlerin yerel halk ve turist için yaşam kalitesini artıracak kısa orta ve uzun vadeli eylem planları hayata geçirilmelidir. Turist deneyimlerini takip edecek araştırmalar, düzenli istatistikî veriler ve geri bildirimler sağlayacak akıllı şehir sistemleri ve şebekeler bu kapsamda geliştirilebilir. Turistin ve yerel toplumun süreci kolaylıkla takip edebilmesi için sosyal medya da dahil olmak üzere geniş bir mecranın bu amaçla kullanılması, harcamaların amacina uygun yapılıp yapılmadığının denetlenmesini de sağlayacaktır.

Türkiye'de mevzuat, yerel yönetimlere yasal olarak herhangi bir konuda vergi koyma yetkisi vermemektedir, ancak yapilacak yeni bir yasal düzenlemeyle bu vergilerin tanımlanması ve belediyelere ilgili yetkilerin devredilmesi mümkün olabilir. Yerinden yönetim ilkesinin bir gereği ve turizmin destinasyon temelinde gerçekleşen bir olay olması nedeniyle gelirin inisiyatifin yerel yönetim organlarına aktarılması oldukça önemlidir. Bu yetkinin yerel yönetimlere tanınması, destinasyon temelinde düzenlemeler yapmak açısından da daha ideal bir çözüm olarak gözükmektedir.

\section{SONUÇ VE DEĞERLENDIRME}

Şehir vergisinin, alanyazındaki tartışmalar ve uluslararası turizmdeki gelişmeler dikkate alındı ̆̆ında, bilinirliği artan bir kavram ve yaygın bir uygulama haline geldiği görülmektedir. Yapılan alan-ülke araştırmalarında, şehir vergisinin 
turizm talebi üzerinde olumsuz etkisinin nadir görüldügü ve buna karşın dünyadaki birçok ülke uygulamasında bu vergilerin turist tarafından kabul edilebilir karşılandığ tespit edilmiştir. Yerel ihtiyaçlar ve ekonomik amaçlarla ortaya çıkan vergilendirmenin daha sürdürülebilir çevre, doğa, toplum gibi hedeflerle daha işlevsel ve geniş bir gerekçe alanına ulaştığı söylenebilir. Bu sürecin bilinçli, sorumlu, duyarlı turist tutum ve davranışlarına paralel olarak daha da gelişeceği tahmin edilebilir.

Şehir vergisinin Türkiye için işlevsel ve çok yönlü katkı sağlayacak yeni bir vergi olacağı öngörülmektedir. Şehir vergisi, kamusal alanda önemli bir yeni gelir özelliğine ve yerel yönetimler için ciddi bir finansman potansiyeline sahiptir. Finansmanın, yerel yönetim birimleri olan ve ölçek olarak destinasyonları kapsayan belediyeler için ve onlar tarafından kullanılması, verginin işlevselliğini artıracaktır. Turizm destinasyonlarını yöneten yerel yönetimlerin, turizmi geliştirecek olanakların artırılması kritiktir. Yaratılacak fonla, öncelikle daha sürdürülebilir destinasyonların yaratılması, turizme doğrudan-dolaylı etkisi olan tüm alt-üst yapı olanaklarının kalitesinin artırılmasına yönelik ihtiyaçların karşılanması gerektiği açıtır.

Şehir vergisinin Türkiye'de uygulanabilirliği, öncelikle ulusal düzeyde kanun koyucu organlar tarafından yapılacak yasal düzenlemelere bağl1dır ancak verginin amacının, destinasyonu ziyaret eden turist ve orada ikamet eden yerel toplumun yaşam standartları, deneyimleri ve çevresel kalitesinin artırılması, sosyal ve kültürel mirasın korunması ve geliştirilmesi temelinde kurgulanması önemlidir. Sürdürülebilirlik perspektifinin turizm ve diğer sektörler üzerindeki somut olumlu etkisi dikkate alındığında, şehir vergisinin meşruiyeti için bu bağlamın yaratılması oldukça önemlidir.

Türkiye' nin uluslararası turizmde rekabet ettiği birçok ülkenin bu vergiyi halihazırda uyguluyor olmasına rağmen, rekabet ve turizm talebi üzerindeki kısa-orta vadeli etkileri izlemek ve buna göre yeni bir yol haritası çıkarmak için uygulamaya geçtikten sonraki ilk süreç önemlidir. Bilinçli ya da çevresel hassasiyetleri yüksek sorumlu turist açısından, şehir vergisine tepkinin olumlu olması beklenebilir. Ancak uygulama sürecinde bunun araştırılması ve turist tutumlarının analiz edilmesi gereklidir. Ayrıca vergi gelirinin etkinliği açısından hem sektörün hem de yerel yönetimlerin bu süreçten nasıl etkilendiği, verginin katkısı ve amaçlara uygun faaliyetler için kullanılıp kullanılmadığı bu süreçte analiz edilmelidir.

Çalışmada teorik bir çerçevede kuramsal bir analiz ve Türkiye üzerine değerlendirmeler yapılmıştır. Araştırma, şehir vergisi açısından neden, niçin ve nasıl sorularına cevap aramış, bunları tartışmış ve öneriler geliştirmiştir. Bu çalışmanın farklı çalışmalarla ve uygulamalı araştırmalarla desteklenmesi gerektiği açıktır. Gelecekteki çalışmaların alan araştırmaları ve paydaşların olası tepkilerini ölçmeye yönelik, özellikle konaklama işletmeleri ile yerli-yabancı turist odaklı çalışmalar olması, bilimsel alanı genişletecek ve alanyazına katkı sağlayacaktır. Ayrıca uygulamadaki senaryoları daha belirgin hale getirebilecektir. Bilimsel gelişme açısından farklı çalışmalara ve tartışma alanına katkı sağlama ümidi, araştırmanın en önemli misyonudur.

\section{KAYNAKÇA}

Aguilo, E., Riera, A. ve Rossello, J. (2005). The Short-Term Price Effect of a Tourist Tax through a Dynamic Demand Model: The Case of Belaric Islands, Tourism Management, 26: 359-365.

Arbel, A. ve Ravid, S. (1983). An Industry Energy Price Impact Model: The Case of the Hotel Industry, Applied Economics, 15: 705-714.

Arguea, M.N. ve Hawkins, R.R. (2015). The rate Elasticity of Florida Tourist Development Taxes, Applied Economics, 47 (18): 1823-1832.

Bender, S. (2007). Lodging Taxation in the United States: A Qualitative Review. (Yayımlanmamış Yüksek Lisans Tezi). Purdue Üniversitesi, Birleşik Devletler, (Yayın No. AAT 1475970).

Brida, A. ve Pereyra, J.S. (2007). The Effects on Environmental Investment of Changes in Tourism Demand, TOURISMOS: An International Multidisciplinary Journal of Tourism, 2 (2): 129-140.

Bonham, C. , Im, E. ve Mak, J. (1992). The Impact of The Hotel Room Occupancy Tax: An Interrupted Time Series Approach, National Tax Journal, 45 (4): 433-441.

Bonham, C. ve Gangnes, B. (1996). Intervention Analysis with Co-Integrated Time Series: The Case of the Hawaii Hotel Room Tax, Applied Economics, 28: 1281-1293. 
Bozdoğanoğlu, B. (2013). Konaklama Vergisi Uygulaması ve Türkiye'de Uygulanabilirliği, Maliye Dergisi, 164, OcakHaziran: 131-149.

Canina, L.-Carvell, S., A. (2005). Lodging Demand for Urban Hotels in Major Metropolitan Markets, Journal of Hospitality \& Tourism Research, 29 (4): 291-311.

Combs, P. ve Elledge, B. (1979). Effects of a Room Tax On Resort Hotels / Motels, National Tax Journal, 32 (2): 201207.

Cural, M. ve Çevik, K.N. (2015). Ekonomik Kalkınmanın Vergi Yapısı Üzerindeki Etkisi: 1924-2013 Dönemi Türkiye Örneği, Amme İdaresi Dergisi, 48 (3): 127-158.

Damonte, L.T. ; Domke-Damonte, D.J. ve Morse, P.S. (1998). The Case for Using Destination-Level Price Elasticity Of Demand For Lodging Services, Asia Pacific Journal of Tourism Research, 3 (1): 19-29.

European Tour Operators Association, Policy Areas, Tourist Taxes, http://www.etoa.org/policyareas/touristtaxes/france, Erişim tarihi: 12 Haziran 2016.

European Tour Operators Association, Policy Areas, Tourist Taxes, $h t t p: / / w w w . e t o a . o r g / p o l i c y a r e a s / t o u r i s t t a x e s / b e l g i-$ um, Erişim tarihi: 12 Haziran 2016.

Feld, P., L. ve Tyran, J., R. (2002). Tax Evasion and Voting: An Experimental Analysis, Kyklos, 55 (2): 197-222.

Fick, G. ve Ritchie, J., R. (1991). Measuring Services Quality in the Travel and Touristy Industry, Journal of Travel Research, 30 (2): 2-9.

Ford, R., C. ve Peeper, W., C. (2007). The Past as Prologue: Predicting the Future of the Convention And Visitor Bureau Industry On The Basis Of Its History, Tourism Management, 28 (4): 1104-1114.

Fujii. E., Khaled, M. ve Mak, J. (1985). The Exportability of Hotel Occupancy and Other Tourist Taxes, National Tax Journal, 38: 169-177.

González, M. ve León, C. (2001). The Adoption of Environmental Innovations in the Hotel Industry of Gran Canaria, Tourism Economics, 7 (2): 177-190.

Gürel, Ç. (2014). Sustaining Tourism Development Through City Tax: The Case of Istanbul, e-Review of Tourism Rese$\operatorname{arch}(e R T R), 11$ (1-2): 26-41.

Gooroochurn, N. ve Sinclair, M. (2003). The Welfare Effects of Tourism Taxation. Discussion Paper Series 2003/2, Christe De Haan Tourism and Travel Research Institute. University of Nottingham.

Gooroochurn, N. ve Sinclair, M. (2005). Economics of Tourism Taxation Evidence from Mauritius, Annals of Tourism Research, 32 (2): 478-498.

Hiemstra, S. ve Ismail, J. (1992a). Analysis of Room Taxes Levied On the Lodging Industry, Journal of Travel Research, 31: 42-49.

Hiemstra, S., ve Ismail, J. (1992b). Occupancy Taxes: No Free Lunch, The Cornell Hotel and Restaurant Administration Quarterly, 33 (5): 84-89.

Hiemstra, S. ve Ismail, J. A. (1993). Incidence of the Impacts of Room Taxes on the Lodging Industry, Journal of Travel Research, 31 (4): 22-26.

http://www.comune.rome.it, Erişim tarihi: 28 Eylül 2016.

Hamburg Tourismus, http://www.hamburg-travel.com/service/ culture-and-tourism-tax/ , Erişim tarihi: 20 Ekim 2016.
Hughes, H. (1981). A Tourism Tax: The Case For and Against, International Journal of Tourism Management, 2 (3): 75-79.

Hughes, H. (1984). Room Taxes-A Response, Tourism Management, Mart: 75-76.

Im, Ericve Sakai, M. (1996). A Note on the Effect of Changes In Ad Valorem Tax Rates On Net Revenue Of Firms: An Application To The Hotel Room Tax, Public Finance Quarterly, 24 (3): 397-403.

Kircheler, E., Hoelzl, E. ve Wahl, I. (2008). Enforced versus Voluntary Tax Compliance: The Slippery Slope, Framework, Journal of Economic Psychology, 29 (2): 210-225.

Knipe, R., T. (2011). Bed Taxes And Local Tourism Development: An Outline And Annotated Bibliography, https:// tomknipe.files.wordpress.com/2010/07/bed-taxes-and-localtourism-development.pdf, Erişim tarihi: 25 Eylül 2016.

Lee, K. S. (2014). Revisiting the Impact of Bed Tax with Spatial Panel Approach, International Journal of Hospitality Management, 41: 49-55.

Mak, J. ve Nishimura, E. (1979). The Economics Of a Hotel Room Tax, Journal of Travel Research, 18: 2-6.

Mak, J. (1988). Taxing Hotel Room Rentals in The U.S., Journal of Travel Research, 27: 10-15.

Official Journal of European Union, 2011, http://eur-lex.Avropa.eu/legal-content/EN/ALL/?uri=OJ:L:2011:077:TOC, Erișim tarihi: 15 Ağustos 2016.

Pintassilgo, P. ve Silva, J. (2007). The Tragedy of Commons" In the Tourism Accommodation Industry, Tourism Economics, 13 (2): 209-224.

Pindyck, R.S. ve Rubinfeld, D.L. (1992). Micro Economics. New York, NY: Macmillan Yayınları.

Sakai, M. (1985). A Micro-Analysis Of Demand For Travel Goods: An Application To The Business Traveler. (Yayımlanmamıs Doktora Tezi). Typescript. Thesis (Ph. D.)University of Hawaii at Manoa, 1985. Bibliography: leaves 81-87.

Scott, D., Peeters, P. ve Gossling, S. (2010). Can Tourism Deliver Its Aspirational Greenhouse Gas Emission Reduction Targets?, Journal of Sustainable Tourism, 18 (3): 393-408.

Serim, N. (2014). Gönüllü Vergi Uyumunu Arttırmada Kamu Otoritesinin Düzenleyici Rolünün Ve Mükellef Çevresinin Önemi: Sıralı Probit Model Yaklaşımı, Afyon Kocatepe Üniversitesi İ̈BF Dergisi, 17 (1): 141-156.

Spengler, J. ve Uysal, M. (1989). Considerations in the Hotel Taxation Process, International Journal of Hospitality Management, 8 (4): 309-316.

Tosun, C. (2001). Challenges of Sustainable Tourism Development in The Developing World: The Case Of Turkey, Tourism Management, 22 (3): 289-303.

National Tax Agency of Japan, http://www.nta.go.jp/foreign_ language/corporation/index.htm, Erişim tarihi: 20 Eylül 2016.

The New York State Department of Tax Nation and Finance, Hotel Room Occupancy Tax,

https://www.tax.ny.gov/pubs_and_bulls/tg_bulletins/st/hotel_ and_motel_occupancy.htm, Erişim tarihi: 22 Eylül 2016.

TUROB STR Global 2017 Ülke Performans Raporu, $h t t p: / /$ www.turob.com/haber.aspx?id=24192, Erişim tarihi: 25 Mayıs 2017. 
Twining-Ward, L. ve Butler, R. (2002). Implementing Sustainable Tourism Development on a Small Island: Development and the Use of Sustainable Tourism Development Indicators in Samoa, Journal of Sustainable Tourism, 10 (5): 363-387.

USA Tax Report (2014). HVS Convention Sports Entertainment $h$ ttps://www.hvs.com/article/7071/2014-hvs-lodgingtax-report-usal, Erişim tarihi: 12 Ekim 2015.

Valle, O.P., Pintassilgo, P. Matias, A. ve André, F. (2012). Tourist Attitudes Towards An Accommodation Tax Earmarked For Environmental Protection: A Survey in the Algarve, Tourism Management, 33: 1408-1416.

Weston, R. (1983). The Ubiquity of Room Taxes, Tourism Management, 4 (3): 194-198.

Winkelblech, P., Clower, T. ve Weinstein, B. (1998). Local Hotel Occupancy Tax Revenues Allocation Sand Conventions and Visitors Bureaus Funding and Spending: A Comparative Analysis, University of North Texas Center for Economic Development and Research, Denton.

The Town Of Greece, https://clients.comcate.com/faq. php?id=231Ertopic=3839, Erişim tarihi: 8 Ekim 2016
Tourism Review, http://www.tourism-review.com/lisbon-newtourist-tax-starting-in-2015-news4331, Erişim tarihi: 10 Ekim 2016

Yakar, S.ve Budak, T. (2013). Bakanlar Kurulunun Vergi Oranını Belirleme Yetkisinin Alt Sınır1: "Sıfır Oran"ın Anlamı, Çukurova Üniversitesi Sosyal Bilimler Enstitüsü Dergisi, 22 (1): 399-426.

\section{Yasa ve Yönetmelikler}

\section{Sayılı Büyükşehir Kanunu}

5393 Sayılı Belediye Kanunu

5779 Sayılı İl Özel İdarelerine ve Belediyelere Genel Bütçe Vergi Gelirlerinden Pay Verilmesi Hakkında Kanun

6360 Sayılı On Dört İlde Büyükşehir Belediyesi ve Yirmi Yedi İlçe Kurulması ile Bazı Kanun ve Kanun Hükmünde Kararnamelerde Değişiklik Yapılmasına Dair Kanun

12/3/1982 tarihli ve 2634 say1lı Turizmi Teşvik Kanununun 37. maddesinin (A) bendinin (2) numaralı alt bendi hükmü uyarınca hazırlanan Turizm Tesislerinin Belgelendirilmesine ve Niteliklerine İlişkin Yönetmelik

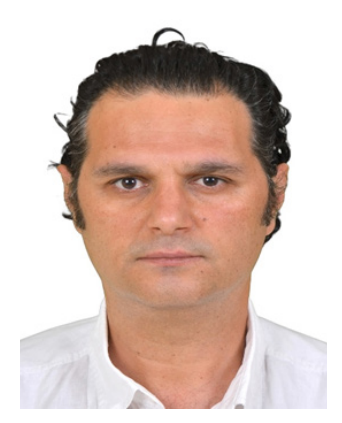

\section{Mustafa DOĞAN}

Kocaeli Üniversitesi İktisadi ve İdari Bilimler Fakültesi Siyaset Bilimi ve Kamu Yönetimi Bölümü'nden 2003 yılında mezun oldu. Yüksek lisans derecesini Çanakkale Onsekiz Mart Üniversitesi'nden Turizm İșletmeciliği dalından (2010), doktora derecesini de Çanakkale Onsekiz Mart Üniversitesi'nden Turizm İşletmeciliği dalından aldı (2014). Çanakkale Onsekiz Mart Üniversitesi'nde Öğretim Görevlisi olarak çalışmaya başladı (2009). Ardından 2014 yııında Batman Üniversitesi Turizm İșletmeciliği ve Otelcilik Yüksekokulu'na Yardımcı Doçent olarak atandı. Halen Batman Üniversitesi Turizm İşletmeciliği ve Otelcilik Yüksekokulu'nda Yardımcı Doçent olarak görev yapmaktadır. Temel çalışma alanları; sürdürülebilir turizm, sürdürülebilir destinasyon yönetimi, ekomüze ve ekoköy gibi yerleşim alanları ve turizm ilişkisi üzerinedir. 